\title{
Complement and immunoglobulins in synovial fluid from synovectomized patients with rheumatoid arthritis
}

\author{
O. J. MELLBYE, B. NAS, AND E. MUNTHE \\ From the Institute of Immunology and Rheumatology, Rikshospitalet, and \\ Oslo Sanitetsforenings Rheumatism Hospital, Oslo, Norway
}

\begin{abstract}
Mellbye, O. J., Næs, B., and Munthe, E. (1976). Annals of the Rheumatic Diseases, 35, 233-239. Complement and immunoglobulins in synovial fluid from synovectomized patients with rheumatoid arthritis. In order to see if the complement $(C)$ consumption and conversion, which are typical of rheumatoid joints, continue after synovectomy, 23 knee joints in which synovectomy had been performed from 4.5 to 6.5 years previously, were studied. The mean ratio of the concentration of $\mathrm{C} 3, \mathrm{C} 4$, and $\mathrm{C} 5$ in synovial fluid to that in plasma of the same patient was significantly lower than the corresponding ratio for the total protein content. This was found both in joints with active arthritis and in joints without clinical signs of arthritis, and in both seropositive and seronegative patients. Conversion products of $\mathrm{C} 3$ were found in 7 of the synovial fluids. The study thus indicated that the complement alterations in synovectomized joints are very similar to those in nonsynovectomized rheumatoid joints.

In one synovial fluid agarose electrophoresis showed multiple sharp bands in the $\gamma$ region. By crossed immunoelectrophoresis some bands seemed to contain IgG with one type of light chains only. In plasma of the same patients the bands were much weaker, indicating local production of oligoclonal IgG in the joint.
\end{abstract}

In most patients with rheumatoid arthritis (RA) normal or increased serum complement concentration and activity is found (Natvig and Winchester, 1969), while in the synovial fluid the complement values are usually lower than in the corresponding protein concentration (Hedberg, 1963; Pekin and Zvaifler, 1964). Complement consumption in the joints seems to be due to fixation to immune complexes in the synovial tissue (Munthe and Natvig, 1971) and in the synovial fluid (Winchester, Agnello, and Kunkel, 1970).

Synovectomy removes the main part of the synovial tissue in a joint. After varying periods of time it is replaced by a new synovium, and in many instances a new arthritis develops. Cracchiolo and Barnett (1969) found that 1 to 2 years after synovectomy, when in most cases the operated joint showed little clinical signs of arthritis, there was much less complement consumption in the joints than before the operation. The purpose of the present investigation was to study complement consumption and activation in joints which had been synovectom- ized as long as 5 years before, and in which clinical signs of relapse of the synovitis had occurred. In addition, since electrophoretic studies of the synovial fluids showed that one patient had multiple bands in the $\gamma$-region not present in his plasma, attempts were made to establish the nature of these bands.

\section{Materials and methods}

SYNOVECTOMIZED PATIENTS WITH RHEUMATOID ARTHRITIS

Nineteen patients (10 males, 9 females) with classical or definite RA, diagnosed according to the criteria of the American Rheumatism Association (McEwen, 1972), were studied. All had undergone synovectomy of 1 or 2 knees at Oslo Sanitetsforenings Rheumatism Hospital from 4.5 to 6.5 years (mean 5.5 years) before study. The mean age at investigation was $\mathbf{5 0}$ years. Synovial fluid was obtained from 23 knee joints, 18 of which showed clinical signs of arthritis. 5 joints appeared to be clinically normal, and from these 5 only 1 to $2 \mathrm{ml}$ of joint fluid was obtained. Details of the preoperative and present clinical status of the patients will be given elsewhere (B. Næs, in preparation). 
PLASMA AND SYNOVIAL FLUID

Plasma was separated from blood which had been drawn with $\mathbf{0 . 0 0 2} \mathrm{mol} / 1$ EDTA. Synovial fluid for complement and immunoglobulin studies was drawn with $0.002 \mathrm{~mol} / \mathrm{l}$ EDTA and centrifuged at $1500 \mathrm{~g}$ for 10 minutes to remove cells before freezing at $-70^{\circ} \mathrm{C}$. Before testing the synovial fluids were treated with hyaluronidase (Penetrase, Leo, Copenhagen) as described by Hedberg (1967). Synovial fluid for routine laboratory examination was drawn with heparin and kept at $+4^{\circ} \mathrm{C}$ until testing.

QUANTITATION OF COMPLEMENT FACTORS AND IMMUNOGLOBULIN CLASSES

This was performed by radial diffusion in gel technique as described by Mancini, Carbonara, and Heremans (1965). Anti-C3, anti-C4, anti-C5, and anti-C3PA/C3A antisera were obtained from Behringwerke AG (Marburg Lahn, West Germany); anti-IgG, anti-IgA, and anti-IgM antisera were produced by immunization of rabbits and subsequent absorption.

CONVERSION PRODUCTS OF C 3 AND C 3 PROACTIVATOR

Conversion products of C3 were tested for by crossed immunoelectrophoresis as described by Laurell (1965), while immunoelectrophoresis was used to detect conversion of $\mathrm{C} 3$ proactivator (C3PA) to $\mathrm{C} 3$ activator (C3A).

TOTAL PROTEIN CONCENTRATION

This was measured by the Folin method, using the modification by Lowry and others (1951).

RHEUMATOID FACTOR

This was tested by a modified Rose-Waaler test as described previously (Mellbye and Natvig, 1970).

ROUTINE LABORATORY TESTING OF SYNOVIAL FLUIDS

This included noting the turbidity and viscosity, mucin test, and microscopy in phase contrast and polarized light of wet preparations (magnification $\times 500$ ). The mucin test was performed by adding $0.5 \mathrm{ml}$ centrifuged fluid to $2 \mathrm{ml}$ of $1.25 \%$ acetic acid. The mean number of cells per field and the relative number of RA cells were recorded by microscopy.

\section{Results}

ROUTINE EXAMINATION OF SYNOVIAL FLUIDS As shown in Table I, most of the synovial fluids showed changes consistent with an active arthritis in the joints. Because of difficulty in obtaining joint fluids from the joints with no clinical activity, only one of these patients (Case 11) was included in the routine examination. Mild changes were found in this fluid.

\section{CONSUMPTION OF COMPLEMENT FACTORS}

In order to see if rheumatoid joints which had been synovectomized 5 years previously showed signs of consumption of complement factors, the ratios of the concentrations of $\mathrm{C4}, \mathrm{C} 3$, and $\mathrm{C5}$ in synovial fluid to those in serum were measured. As there is usually a lower concentration of proteins in synovial fluid than in serum, the ratios for the complement factors were compared with the corresponding ratio for the total protein content. As shown in Table II, the lowest mean ratio was observed for $\mathrm{C} 4$; but ratios for $\mathrm{C} 3$ and $\mathrm{C5}$ when measured by Student's ' $t$ ' test were significantlyo lower than the corresponding ratios for the total protein content $(\mathrm{P}<0.05)$. Thus, there seemed to be a specific consumption of these complement factors in joints which had undergone synovectomy. Also, as shown in Table II, the mean ratios for the complement factors in seropositive patients was lower than those of the seronegative patients, but the differences were not statistically significant $(P>0.05)$. In both groups the ratios for the complement factors were significantly lower than the corresponding ratios for the total protein content.

Table I Routine examination of 14 joint fluids from synovectomized joints

\begin{tabular}{|c|c|c|c|c|c|c|c|}
\hline Case no. & Turbidity* & Viscosity $\dagger$ & $\begin{array}{l}\text { Mucine } \\
\text { test }\end{array}$ & $\begin{array}{l}\text { Cells/field } \\
\text { (mean numbers) }\end{array}$ & $\begin{array}{l}\text { RA cells } \\
(\% \text { of all cells })\end{array}$ & $\begin{array}{l}\text { Lipid } \\
\text { droplets }\end{array}$ & $\begin{array}{l}\text { Degree of } \\
\text { changes }\end{array}$ \\
\hline $\begin{array}{r}1 \\
2 \\
3 \\
4 \\
5 \\
6 \\
7 \\
8 \\
9 \\
10 \\
11 \\
12 \\
13 \\
14\end{array}$ & $\begin{array}{l}+ \\
\mathbf{N} \\
++ \\
+ \\
+ \\
\mathbf{N} \\
+++ \\
\mathbf{N} \\
+++ \\
\mathbf{N} \\
+ \\
+ \\
++ \\
++\end{array}$ & $\begin{array}{l}++ \\
\mathrm{N} \\
+++ \\
+++ \\
+++ \\
\mathrm{N} \\
+++ \\
+ \\
+++ \\
+ \\
++ \\
+++ \\
++ \\
++\end{array}$ & $\begin{array}{l}\text { Medium } \\
\text { Good } \\
\text { Poor } \\
\text { Medium } \\
\text { Poor } \\
\text { Good } \\
\text { Poor } \\
\text { Good } \\
\text { Poor } \\
\text { Medium } \\
\text { Medium } \\
\text { Poor } \\
\text { Medium } \\
\text { Poor }\end{array}$ & $\begin{array}{c}10-15 \\
1-5 \\
100 \\
10-15 \\
20-30 \\
<5 \\
30-50 \\
1-5 \\
30-50 \\
20-30 \\
5-10 \\
20-50 \\
30-50 \\
50-100\end{array}$ & $\begin{array}{l}- \\
\overline{50} \\
- \\
- \\
- \\
- \\
\overline{50} \\
<5 \\
- \\
- \\
<2 \\
5\end{array}$ & $\begin{array}{l}- \\
\bar{t} \\
\overline{(+} \\
\bar{t} \\
\overline{+} \\
+ \\
+ \\
- \\
\bar{t} \\
+\end{array}$ & $\begin{array}{l}\text { Medium } \\
\text { Mild } \\
\text { Strong } \\
\text { Medium } \\
\text { Strong } \\
\text { Mild } \\
\text { Strong } \\
\text { Mild } \\
\text { Strong } \\
\text { Medium } \\
\text { Mild } \\
\text { Strong } \\
\text { Strong } \\
\text { Strong }\end{array}$ \\
\hline
\end{tabular}

* $\mathbf{N}=$ clear or normal $+=$ slightly unclear; $++=$ definitely unclear; $+++=$ purulent.

$+\mathbf{N}=$ normal $+=$ slightly decreased $;++=$ definitely decreased $++++=$ strongly decreased.

Microcrystals were not detected in the fluids, but birefringent 'Malteser crosses' were sometimes seen in the lipid droplets. 
Table II Mean ratio $( \pm 1 S E)$ of concentration in synovial fluid to concentration in plasma of complement factors in synovectomized joints (no. of joints in parentheses)

\begin{tabular}{|c|c|c|c|}
\hline Protein measured & All joints examined & Joints in $R F+$ patients & Joints in $R F-$ patients \\
\hline $\begin{array}{l}\text { C4 } \\
\text { C3 } \\
\text { C5 } \\
\text { Total protein }\end{array}$ & $\begin{array}{l}0.20 \pm 0.02(23) \\
0.28 \pm 0.03(23) \\
0.35 \pm 0.04(20) \\
0.53 \pm 0.03(23)\end{array}$ & $\begin{array}{l}0.17 \pm 0.02(15) \\
0.27 \pm 0.03(15) \\
0.34 \pm 0.04(13) \\
0.52 \pm 0.04(15)\end{array}$ & $\begin{array}{l}0.24 \pm 0.06(8) \\
0.31 \pm 0.04(8) \\
0.38 \pm 0.06(7) \\
0.57 \pm 0.06(8)\end{array}$ \\
\hline
\end{tabular}

Some joints were not examined in all tests because of lack of synovial fluid.

Moreover as shown in Table III, there was no significant difference between the ratios for the complement factors when comparing joints with clinically active arthritis and joints without clinically demonstrable arthritis. The same lack of significance was found when comparing joints with the strong changes in the joint fluids as judged by routine examination and joints with mild or medium changes.

\section{CONVERSION OF C3 AND C3PA}

In order to see if conversion of $\mathrm{C} 3$ could be observed in synovectomized joints, all the synovial fluids and sera were tested by crossed immunoelectrophoresis against anti-C3 antiserum. Partial conversion into a more anodically moving fragment was observed in 8 of the 23 joint fluids (Fig. 1). In 3 joint fluids the conversion was very weak, two of these were the only ones seen in the seronegative group, the third was the only conversion seen among the joints without clinically active arthritis. Thus, the 5 joints with the most pronounced $\mathrm{C} 3$ conversion were all from seropositive patients with clinically active arthritis. Conversion of $\mathrm{C} 3$ was not observed in any sera. The synovial fluid and sera were also tested for conversion of C3PA to C3A by immunoelectrophoresis and no such conversion was observed.

Table III Mean ratio ( $\pm 1 S E)$ of concentration in synovial fluid to concentration in plasma of complement factors in synovectomized joints (no. of joints in parentheses)

\begin{tabular}{|c|c|c|c|c|}
\hline \multirow[t]{2}{*}{ Protein } & \multicolumn{2}{|c|}{ Clinical activity in joint } & \multicolumn{2}{|c|}{ Changes in synovial fluid by general routine examination } \\
\hline & Active arthritis & No arthritis & Strong & Mild/medium \\
\hline $\begin{array}{l}\text { C4 } \\
\text { C3 } \\
\text { C5 } \\
\text { Total protein }\end{array}$ & $\begin{array}{l}0.20 \pm 0.03(18) \\
0.31 \pm 0.03(18) \\
0.39 \pm 0.04(14) \\
0.55 \pm 0.03(18)\end{array}$ & $\begin{array}{l}0 \cdot 17(5)^{*} \\
0 \cdot 19(5) \\
0 \cdot 20(4) \\
0.47(5)\end{array}$ & $\begin{array}{l}0.18 \pm 0.03(7) \\
0.28 \pm 0.05(7) \\
0.38 \pm 0.06(6) \\
0.54 \pm 0.06(7)\end{array}$ & $\begin{array}{l}0.22 \pm 0.06(7) \\
0.32 \pm 0.05(7) \\
0.36 \pm 0.06(7) \\
0.53 \pm 0.05(7)\end{array}$ \\
\hline
\end{tabular}

Some joints were not examined in all tests because of lack of synovial fluid.

* SE not given because of the low number of joints in this group.

\section{Plasma}

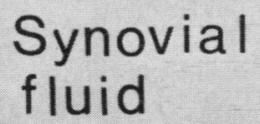

FIG. 1 Case 9. Crossed immunoelectrophoresis against anti-C3 antiserum of plasma and synovial fluid from a synovectomized rheumatoid joint. Anode to the right and top. The plasma contains only the peak representing native $C 3$; in the synovial fluid an additional peak, representing a conversion product of $C 3$, can be seen 
GAMMAGLOBULIN BANDS IN SYNOVIAL FLUID During agarose gel electrophoresis, which was the initial step of the crossed immunoelectrophoresis, it was discovered that in one of the synovial fluids there were at least 4 clearly visible sharp bands in the gammaglobulin region. In the corresponding plasma only 3 very faint lines could be observed (Fig. 2). By crossed immunoelectrophoresis against antisera to $\operatorname{IgG}, \operatorname{IgA}$, and $\operatorname{IgM}$, the bands were identified as IgG (Fig. 3). Further crossed immunoelectrophoresis against antisera to type $\kappa$ and $\lambda$ light chains (Fig. 4) indicated that two of the bands in the synovial fluid contained type $\kappa$ light chains only, while the 2 other bands seemed to contain both type $\kappa$ and $\lambda$ light chains.

This synovial fluid/plasma pair was from a male patient, 63 years old, who had been synovectomized 6 years before the examination. He had seronegative arthritis, with severe and typical destruction of the joints. At follow-up examination he had clinically active arthritis in the synovectomized joint, and by routine testing the synovial fluid showed pronounced changes consistent with active arthritis (Table I, Case 5). This patient was the only one who had a higher concentration of $\mathrm{IgG}$ in the synovial fluid than in the plasma, namely $16.0 \mathrm{mg} / \mathrm{ml}$ versus $12.0 \mathrm{mg} / \mathrm{ml}$.

\section{Discussion}

Both the demonstration of a specific consumption of $\mathrm{C} 3, \mathrm{C} 4$, and $\mathrm{C} 5$ in previously synovectomized rheumatoid joints and the demonstration of conversion of
C3 in many of the same joints indicate that these immunological processes, which are considered to be typical for rheumatoid joints (Hedberg, Lundh, and Laurell, 1970; Lundh, Hedberg, and Laurell, 1970; Ruddy and Austin, 1970), recur in the joints after synovectomy. The partial normalization of some of these parameters observed after synovectomy by Cracchiolo and Barnett (1969) seems therefore to be transient. Moreover, our results agree with those of Gabay, Micheli, and Fallet (1975) who found little influence of chemical synovectomy on the $\mathrm{C} 3$ alterations in rheumatoid joints. Together with our finding of the same changes which are usually seen in rheumatoid synovial fluids by routine examination, these studies support the concept that RA expresses itself by the same mechanism when the rheumatoid process starts again in a synovectomized joint.

It is surprising that the specific complement consumption also seemed to take place in joints with little or no clinical signs of arthritis. Such a discrepancy between clinical activity and complement alterations was, however, already noted by Hedberg (1967) and by Cracchiolo and Barnett (1969). If it is assumed that complement activation is directly responsible for joint inflammation, this discrepancy is difficult to understand. It seems that either the complement consumption in arthritic joints does not always lead to formation of fragments and complexes which induce inflammation, or the arthritic inflammation is at least partly released by other factors than complement activation. The finding of RA in some patients

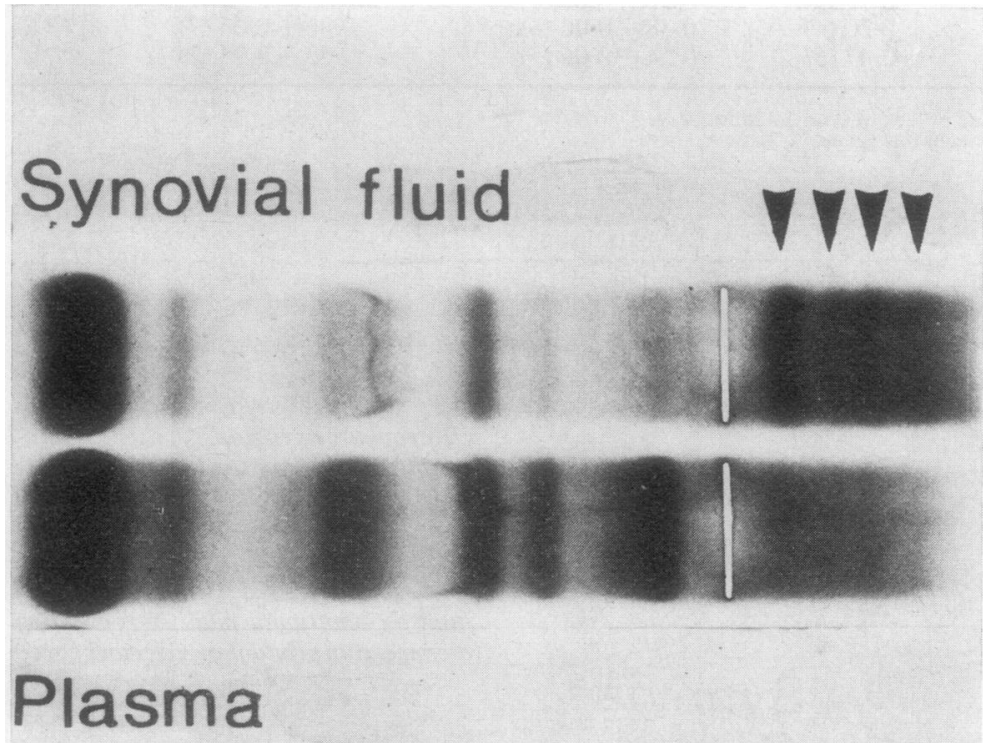

FIG. 2 Case 5. Agarose gel electrophoresis of synovial fluid from a synovectomized rheumatoid joint and plasma from the same patient. Anode to the left. The arrows indicate 4 sharp gammaglobulin bands in the synovial fluid, 3 of them faintly visible also in plasma 


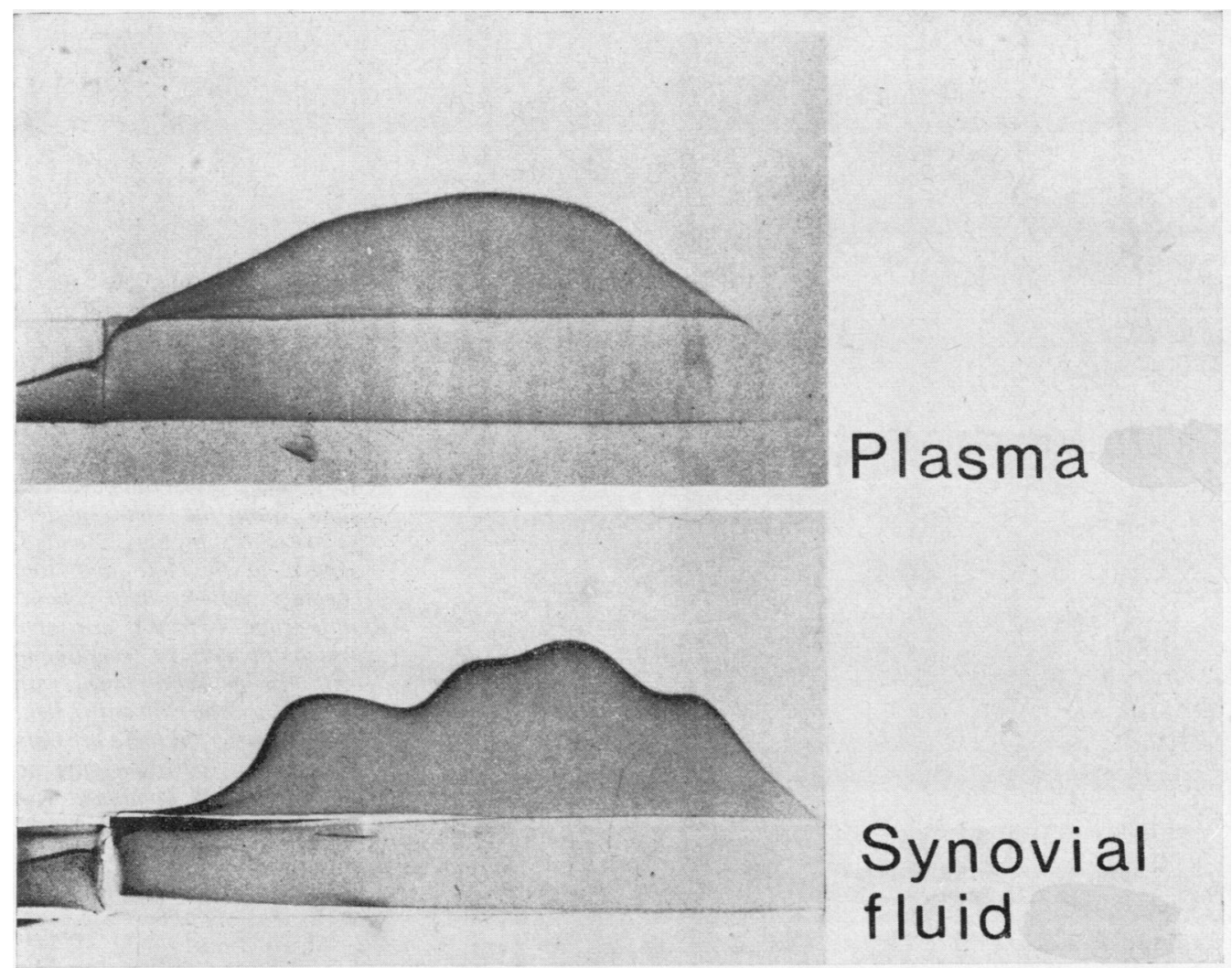

FIG. 3 Case 5. Crossed immunoelectrophoresis against anti-IgG antiserum of synovial fuid and plasma from the same patient as in Fig. 2. Anode to the left and top. Four peaks can be seen in the synovial fluid, not visible in the plasma

with agammaglobulinaemia (Good and Rotstein, 1960) seems to favour the latter possibility; however, there is some indication of complement activation by the alternate pathway in these cases (Munthe and others, 1975).

In spite of the evidence for $\mathrm{C} 3$ consumption in the joints, we found no conversion products of $\mathrm{C} 3$ in any of the plasmas and in few synovial fluids. This agrees with similar studies by Hedberg and others (1970) in nonsynovectomized rheumatoid patients, and might be due to the very short half-life of $\mathrm{C} 3$ degradation products (Alper, Rosen, and Watson, 1967). However, these results seem to differ from those of Versey, Hobbs, and Holt (1973) who found C3 conversion in most plasmas from nonsynovectomized rheumatoid patients. The lack of conversion of C3PA to C3A in both plasma and synovial fluid in the present study may also be surprising, since there is evidence for alternate pathway activation of complement in rheumatoid joints obtained by various techniques, among them detection of conversion of C3PA by immunoelectrophoresis as used here (Zvaifler, 1974). Further studies are needed to determine whether these discrepancies are due to a difference in sensitivity of the techniques or to the selection of synovectomized patients for this study.

Faint narrow bands in the $\gamma$-region at electrophoresis have been observed by Hedberg (1971) in 12 out of 41 rheumatoid sera and in eluates from rheumatoid synovial tissue (J. B. Natvig and B. Vandvik, unpublished observations). In only one of Hedberg's cases were the bands stronger in the synovial fluid than in serum, as in the case found in the present investigation. Our crossed immunoelectrophoresis experiments indicated that some of the bands in the synovial fluid contained IgG with type $\kappa$ light chain only, while other bands seemed to contain both $\kappa$ and $\lambda$ light chains. Thus, at least some of the bands seemed to contain IgG molecules with restricted heterogeneity with respect to light chain type. A similar oligoclonal pattern can be produced during active immunization of animals (Krause, 1970). This pattern may also occur in cerebrospinal fluid in man, especially in systemic sclerosing panencephalitis and multiple sclerosis. At least in the former disease, the bands have been shown to represent antibodies to various virus determinants (Vandvik and Norrby, 1973). 


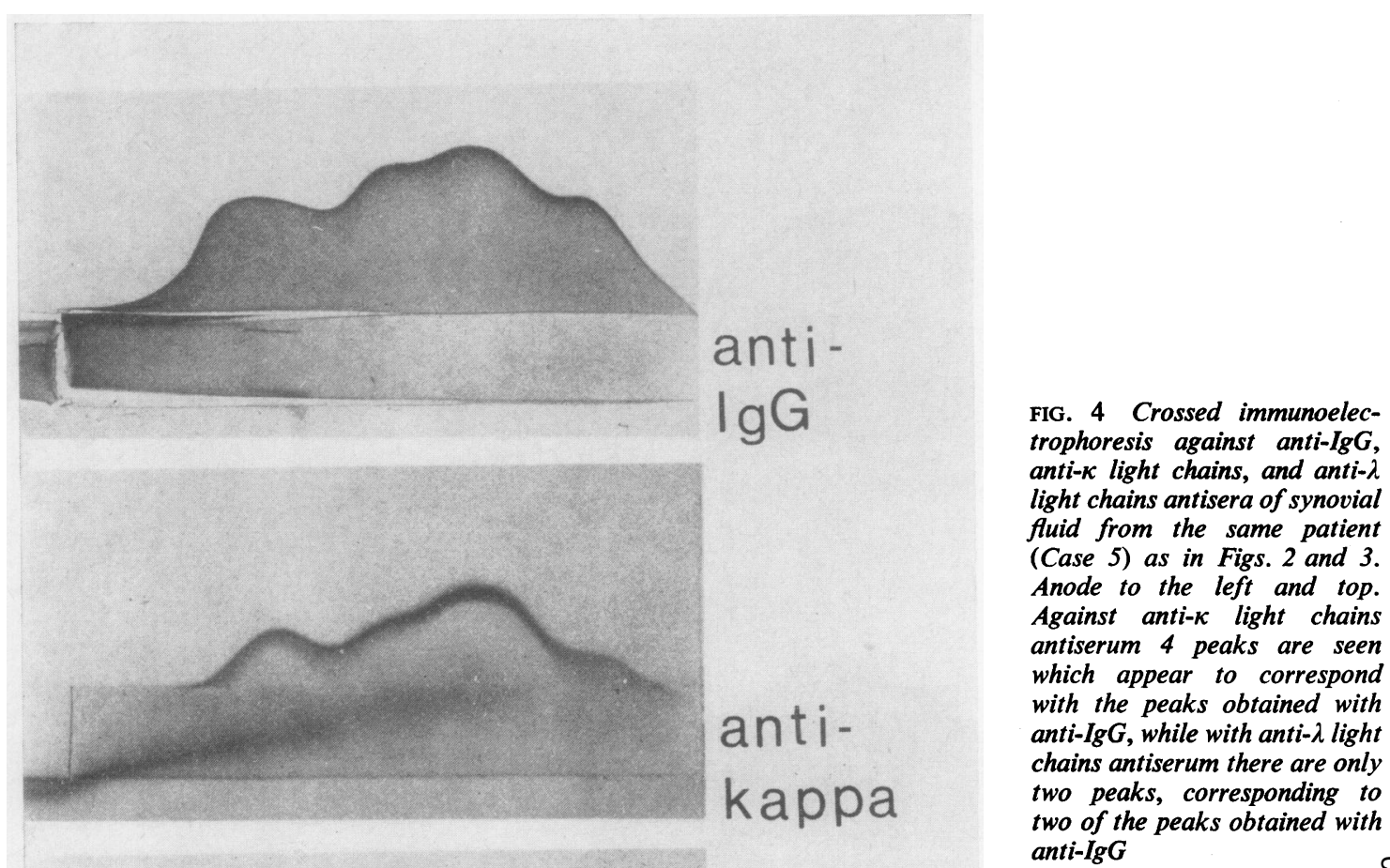
fluid from the same patient (Case 5) as in Figs. 2 and 3. Anode to the left and top. Against anti- $\kappa$ light chains antiserum 4 peaks are seen which appear to correspond with the peaks obtained with anti-IgG, while with anti- $\lambda$ light chains antiserum there are only two peaks, corresponding to anti-IgG

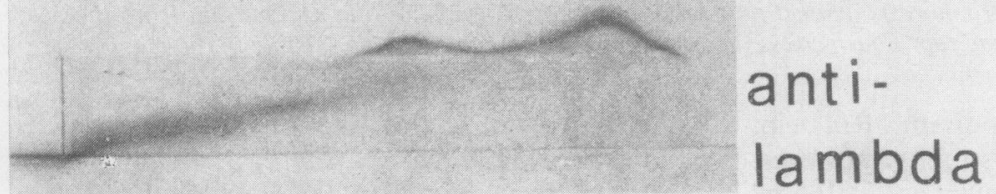

It is tempting to suggest that IgG bands in rheumatoid synovial fluid, not present in the corresponding serum, represent an active antibody response to an agent of importance in the pathogenesis of the arthritis. It might be expected that such bands would be found more commonly in rheumatoid synovial fluid. It may be that they are present only during a certain phase during the immunization process, as shown in animals (Krause, 1970). It has been shown repeatedly, by serological methods (Hannestad and Mellbye, 1967), by tissue culture experiments
(Smiley, Sachs, and Ziff, 1968), and by immunofluorescence (Munthe and Natvig, 1971) that the rheumatoid synovial tissue produces immunoglobulin. Obviously, a large part of the antibodies produced are rheumatoid factors, which may account for approximately half of the immunoglobulin production. The specificity of the rest of the antibodies produced is still unknown.

We are indebted to Dr. J. Pahle for valuable suggestions, and to Mrs. Mona Hauger for skilful technical assistance.

\section{References}

Alper, C. A., Rosen, F. S., AND Watson, L. (1967) J. clin. Invest., 46, 2021 (Studies of the in vivo behaviour of human $C^{\prime} 3$ in normal subjects and patients)

Cracchiolo, A., AND Barnett, E. V. (1969) J. Bone Jt Surg., 51A, 475 (Immunologic changes in synovial fluid following synovectomy of the knee for rheumatoid arthritis) 
Gabay, R., Micheli, A., AND Fallet, G. H. (1975) Ann. rheum. Dis., 34, 166 (Behaviour of synovial complement $\mathrm{C} 3$ and $\mathrm{C} 4$ components in inflammatory and degenerative joint diseases, before and after synoviorthesis)

Good, R. A., AND RotsteIN, J. (1960) Bull. rheum. Dis., 10, 203 (Rheumatoid arthritis and agammaglobulinemia)

HANNESTAD, K., AND MellbYe, O. J. (1967) Clin. exp. Immunol., 2, 501 (Rheumatoid factor in synovial effusions: local production and consumption)

HEDBERG, H. (1963) Acta rheum. scand., 9, 165 (Studies on the depressed hemolytic complement activity of synovial fluid in adult rheumatoid arthritis)

(1967) Acta med. scand., Suppl. 479 (Studies on synovial fluid in arthritis. I. The total complement activity) (1971) Ann. clin. Res., 3, 281 (Faint, narrow bands in the $\gamma$-region visible at agarose electrophoresis. The occurrence in various forms of arthritis)

- LUNDH, B., AND LAURell, A.-B. (1970) Clin. exp. Immunol., 6, 707 (Studies of the third component of complement in synovial fluid from arthritic patients. II. Conversion and its relation to total complement)

KraUse, R. M. (1970) Advanc. Immunol., 12, 1 (The search for antibodies with molecular uniformity)

LAURell, C.-B. (1965) Analyt. Biochem., 10, 358 (Antigen-antibody crossed electrophoresis)

Lowry, O. H., Rosebrough, N. J., Farr, A. L., ANd Randall, R. J. (1951) J. biol. Chem., 193, 265 (Protein measurement with the Folin phenol reagent)

Lundh, B., Hedberg, H., and Laurell, A.-B. (1970) Ciin. exp. Immunol., 6, 407 (Studies of the third component of complement in synovial fluid from arthritic patients. I. Immunochemical quantitation and relation to total complement)

MCEWEN, C. (1972) 'The diagnosis and differential diagnosis of rheumatoid arthritis' in 'Arthritis and Allied Conditions', eds. J. L. Hollander and D. J. McCarty, 8th ed., p. 403. Lea and Febiger, Philadelphia

Mancini, G., Carbonara, A. O., and Heremans, J. F. (1965) Immunochemistry, 2, 235 (Immunochemical quantitation of antigens by single radial diffusion)

Mellbye, O. J., AND NATVIG, J. B. (1970) Clin. exp. Immunol., 7, 257 (Experimentally produced antibodies to the pepsin site of IgG due to untreated autologous IgG in immune complexes)

MunTHE, E., AND NATVIG, J. B. (1971) Ibid., 8, 249 (Characterization of IgG complexes in eluates from rheumatoid tissue)

- , Høyeraal, H. M., Frøland, S. S., Mellbye, O. J., Kåss, E., and Natvig, J. B. (1975) Rheumatology, 6, 43 (Evidence for complement activation by the alternate pathway in the arthritis of hypogammaglobulinemic patients)

NATVIG, J. B., AND Winchester, R. J. (1969) Acta rheum. scand., 15, 161 (Complement in rheumatoid inflammation)

Pekin, T. J., ANd Zvaifler, N. J. (1964) J. clin. Invest., 43, 1372 (Hemolytic complement in synovial fluid)

RudDY, S., AND Austin, K. F. (1970) Arthr. and Rheum., 13, 713 (The complement system in rheumatoid synovitis. I. An analysis of complement component activities in rheumatoid synovial fluids)

Smiley, J. D., SACHS, C., AND ZIFF, M. (1968) J. clin. Invest., 47, 624 (In vitro synthesis of immunoglobulin by rheumatoid synovial membrane)

VANDVIK, B., AND Norrby, E. (1973) Proc. nat. Acad. Sci. (Wash.), 70, 1060 (Oligoclonal IgG antibody response in the central nervous system to different measles virus antigens in subacute sclerosing panencephalitis)

Versey, J. M. B., HobBs, J. R., AND Holt, P. J. L. (1973) Ann. rheum. Dis., 32, 557 (Complement metabolism in rheumatoid arthritis. I. Longitudinal studies)

Winchester, R. J., AGNello, V., AND KUNKel, H. G. (1970) Clin. exp. Immunol., 6, 689 (Gamma globulin complexes in synovial fluids of patients with rheumatoid arthritis. Partial characterization and relationship to lowered complement levels)

ZvaIfLer, N. J. (1974) Arthr. and Rheum., 17, 297 (Rheumatoid synovitis. An extravascular immune complex disease) 